\title{
RECAPITULATION: A TECHNIQUE OF CHARACTER PORTRAYAL IN 'CELESTINA'
}

\author{
R. Roger Smith \\ Indiana University of Pennsylvania
}

"O Calisto y Melibea, causadores de tantas muertes, mal fin ayan vuestros amores, en mal sabor conviertan vuestros dulçes plazeres," (298) laments Elicia as she brings to the audience's attention for the third time ${ }^{2}$ the death of her mentor, Celestina, murdered by Sempronio and Pármeno. The author of Celestina $a^{3}$ makes frequent use of restatements of information-such as this one-to accomplish a number of ends: characterization, emphasis, establishment of causality, amplification, multiple perspective, and summary, to name but some of these ends. I will examine the first of these, characterization, to show how Fernando de Rojas works with recapitulations to enhance character portrayal, long recognized as a salient feature of the Tragicomedia. 4

${ }^{1}$ Fernando de Rojas, La Celestina, ed. and introd. D. S. Severin (Madrid: Cátedra, 1988). All citations are from this ed. and will be identified in the text by page numbers.

${ }^{2}$ At the moment when Celestina is murdered, Elicia recounts what has happened and, in so doing, expresses her profound sense of loss ("Muerte es mi madre y mi bien todo," 275); en route to see Areúsa, Elicia recalls the murder, saying to herself: "Si ha sabido las tristes nuevas que yo le traygo, no avré yo las albricias de dolor que por tal mensaje se ganan" (294). The compelling desire to be first with the news alleviates somewhat the grief expressed earlier.

${ }^{3}$ A detailed account of the various titles with which this work has been identified is: Erna R: Berndt-Kelley, "Peripecias de un título: en torno al nombre de la obra de Fernando de Rojas," in Celestinesca 9, ii (Nov. 1985): 3-46.

"María Rosa Lida de Malkiel, Two Spanish Masterpieces. The "Book of Good Love" and the "Celestina" (Illinois Studies in Language and Literature, 49, Urbana: U of Illinois P, 1961), 84. "Among all the dramatic works written in Spanish the Tragicomedia de Calisto y Melibea is unsurpassed in the creation of characters." 
A story's narrator, traditionally omniscient (although some times not totally), serves to externalize for the audience the internal thought processes and motivational patterns of the characters. The absence of a narrator, as in Celestina, and of a character (or characters) who can be claimed to be speaking for the author places great artistic distance between the creative hand and the individual response of characters to conflicts. It gives free rein to the imagination and leaves interpretation in the hands of the audience. However, Rojas did not leave to chance entirely this matter of interpretation: the narrator's voice can be heard in the dialogue of his created characters. ${ }^{5}$ In the absence of the omniscient narrator, Rojas utilizes techniques of recapitulation-at least in part-to communicate, to speak to his audience.

Recapitulation serves principally to restate information, e. g., about an event that has taken place, or about statements or conversations heard earlier. Such recapitulations may take place in private, or in new conversational groups. As the characters create these new versions of previous action and dialogue, they are revealing themselves more completely known to the audience. These restatements can exaggerate, contradict, confirm or deviate from a previous version and thus allow the audience to make ongoing assessments and judgments about particular characters. Lida de Malkiel affirms that the audience indeed must rely only on what is said, "ya que no de otro modo conocemos lo que se debate en el fondo de su alma" (LOA, 288). The disparity between appearance and reality is often highlighted in the recapitulations, perhaps even more effectively than by the uses of foreshadowing, as studied by K. K. Phillips. ${ }^{6}$ As D. C. Muecke notes, "there is perhaps less scope for an ironist to be subtle when he is depending on our prior knowledge of something to contradict what he asserts of it." In Celestina, Rojas' judicious, purposeful use of recapitulations steers the audience's attention toward the incongruities and paradoxes throughout.

Recapitulations operate through and depend upon the memory of individual

${ }^{5}$ M. R. Lida de Malkiel, La originalidad artistica de "La Celestina" (Buenos Aires: EUDEBA, $\left.1970^{2}\right)$, 287. "El autor se dirige al espectador por encima de los interlocutores del diálogo, dejando entrever la trayectoria total del personaje en cuestión."

6 "Ironic Foreshadowing in La Celestina," Kentucky Romance Quarterly 21 (1974), 474. "Upon re-reading the text one becomes increasingly aware of the unconscious irony that predominates, be it verbal or dramatic." Phillips notes that recapitulation plays a role in Celestina but does not develop the point in her study.

'Douglas Colin Muecke, Irony (London: Methuen, 1970), 53. 
characters. When a character recalls information given earlier and pertinent to a new situation, the audience is led to match memories-its own with the characters'-and to make new valuations of the speaker. D. S. Severin in Memory in "La Celestina" showed several ways in which memory contributes to Rojas' portrayal of character. Let me briefly recall one illustration. Before Celestina enters Calisto's house for the first time, Pármeno reveals to Calisto his own prior acquaintance with the bawd. After she enters the house, Severin writes, Celestina "attempts to invite Pármeno's complicity by recalling their past together" (21). She asks: "¿Acuérdaste, quando dormías a mis pies, loquito?" to which Pármeno responds: "Si, en buena fe; y algunas vezes, aunque era niño, me subías a la cabecera y me apretavas contigo, y porque olías a vieja, me huýa de ti" (120). Severin observes that "[t]he ability of the aged memory to whitewash and idealize the past is here defeated by the realism of the 'nueva memoria' (21).

To exercise an interpretative or selective memory is a trait of human nature. That Celestina and Pármeno follow this practice reinforces the audience's perception of this trait in these two characters. It is here that the act of recapitulation provides an essential link that enables the audience to recognize the implications of what is being said. Having already heard Pármeno's description of his prior acquaintance with Celestina, the audience may readily concur with Severin's observation noted above.

The use of recapitulation is a significant feature of character portrayal in Celestina in that characters' "various fates are a direct result of what they have been and done throughout the story. "This technique can be used to intensify a portrayal, to indicate a change in character, and to delineate character flaws. Simultaneously, the recapitulations enhance atmosphere, establish motivation, provide structural unity, and contribute to the audiences's recognition of the ironic twists of the story. The following discussion will further examine the role that the recapitulations play specifically in the portrayal of the five principal characters: Celestina, Pármeno, Sempronio, Calisto and Melibea.

Celestina is the prime mover in this story of the two unfortunate lovers because she, sabia y malvada, demonstrates time and again that she is capable of

"Dorothy Sherman Severin, Memory in "La Celestina" (London: Tamesis, 1970), 19-42. Additional quotations will be noted in the text.

9 June Hall Martin, Love's Fools: Aucassin, Troilus, Calisto and the Parody of the Courtly Lover (London: Tamesis, 1972), 97. 
manipulating each of the characters with whom she comes in contact. During Celestina's first visit with Melibea, the bawd states that she has come to serve the interests of another party. In order to arouse the sympathies of Melibea, the gobetween restates and amplifies the purpose of her visit, saying that "Yo dexo un enfermo a la muerte, que con sola una palabra de tu noble boca salida, (...) tiene por fe que sanará" (159). The audience already knows the intent of Celestina's mission and therefore is aware of the irony conveyed by her choice of words as she attempts to manipulate Melibea by restating in these terms the nature of Calisto's malady. After this initial visit, Celestina congratulates herself: "Y qué tan cercana estuve de la muerte, si mi mucha astucia no rigera con el tiempo las velas de mi petición. ¡O amenazas de donzella brava, o ayrada donzella!"(171). Whereas Celestina attributes her narrow escape to her considerable ability to manipulate others, the audience knows that she is exaggerating the gravity of her situation. Her tendency to exaggerate is revealed as a trait of Celestina's character.

In a series of additional recapitulations of her visit with Melibea $(179,181-$ 184), Celestina narrates, while liberally embellishing the facts for Calisto's ears, what had transpired. A comparison between the real event and its recapitulations by: Celestina makes it apparent that her motive is to manipulate the love-smitten young man's feelings in order to increase anticipated compensation for her services. The recapitulation further intensify the audience's perception of Celestina as a manipulator of reality.

Recapitulations play a significant role also in Celestina's efforts to manipulate Pármeno, her most difficult challenge. Severin states that "Pármeno, as always, recognizes the interrelationship and causality in past and present events" (23). However, Lida de Malkiel assures us that "los ojos intelectuales de Celestina penetran a todos los personajes" (LOA 520) and, aware of Pármeno's style of reasoning, Celestina prefaces the scene of his liaison with Areúsa with an attempt to awaken in Pármeno feelings of guilt. This psychological ploy commences as the bawd recalls their earlier conversation (Act I): "Si tú tovieras memoria, hijo Pármeno, del pasado amor que te tuve, la primera posada que tomaste venido nuevamente a esta cibdad, havía de ser la mia" (193). Because this information lacks corroboration and the audience is now alert to Celestina's embellishments, they suspect a discrepancy between the past as described by Celestina and the true nature of this past shared with Pármeno. Thus they can view Celestina's comments as one further attempt to manipulate Pármeno.

In her efforts to overcome Pármeno's seemingly constant misgivings, Celestina must continue the assault. She recalls for him the moment (184-185) when "de lástima que ove de verte roto pedí hoy manto, como viste, a Calisto; no por mi 
manto, pero por que, estando el sastre en casa y tú delante sin sayo, te le diesse. Assí que por no mi provecho, (...) mas por el tuyo (...)" (195). In reality, Calisto, concerned that his servant's horrified reaction to the go-between's arrival might jeopardize Celestina's willingness to "cure" him, had previously offered the garment to Pármeno. (114). What we learn in this scene is that the astute bawd makes the memory of this detail work to her advantage and, in so doing, manipulates Pármeno so as to secure his compliance for the deal she has in hand with respect to Calisto.

During the strife-filled moments that precede the murder of Celestina, the topic of conversation turns to the promises that the bawd had made (173) with regard to the reward. She acknowledges "que te dixe (...) que quanto yo tenía era tuyo," but she interprets this memory also adding that "estas palabras de buen amor, no obligan" (270). Celestina's straightforward remark intensifies Sempronio's frustration and he protests: "¿Quién la oyó esta vieja dezir que me llevasse yo todo el provecho, si quisiesse, deste negocio, pensando que sería poco?" (272). ${ }^{10}$ Sempronio realizes now that, in spite of his certain knowledge of Celestina's avarice, he has foolishly allowed himself to be manipulated by her.

In the next few moments when the overweening, disgruntled servants pose an imminent threat to her life, it is ironic that the usually astute bawd does not fend off her adversaries with further attempts at manipulation, her stock-in-trade. Sempronio reminds the go-between of her previous promise (115) that all would share any profit that might accrue from this venture when he asks, "¿no serás contenta con la tercera parte de lo ganado?" (274). Celestina, not willing to share, feigns ignorance of this promise whereupon Sempronio summarizes her choices: "tú complirás lo que prometiste o complirás hoy con tus días" (274). The recapitulations stated immediately prior to Celestina's violent death make it unmistakably clear that she falls victim to a fatal flaw, her own need and the greed that grows from it.

As noted above, Pármeno is the character who seems to be most resistant to Celestina's manipulative efforts. At first, his voice is the sole voice of reason amidst the cacophony of greed, lust and self-interest. In response to Calisto's unreasoned lamentations, Pármeno recounts to his master with measured cause-andeffect manner the unfolding of events that occurred at the impromptu meeting of Calisto and Melibea in the garden. The servant summarizes:

${ }^{10}$ John Lihani, "The Intrinsic and Dramatic Values of Celestina's Gold Chain," in Studies in Honor of Gerald E. Wade, ed. S. Bowman et al (Madrid: Porrúa, 1979), 157. Lihani calculates that the chain "could have represented, in today's relative terms, anywhere from a three thousand to a seven thousand five hundred dollar investment." He also discusses the importance to Rojas' audience of techniques of recapitulation. 
Señor, porque perderse el otro día el neblí fue causa de tu entrada en la huerta de Melibea a le buscar; la entrada causa de la veer y hablar; la habla engendró amor; el amor parió tu pena; la pena causará perder tu cuerpo y el alma y hazienda. (134-135)

Pármeno's dispassionate recapitulation earns him the trust of the audience. However, he not only recounts the sequence of past events, but, as the future tense in the last phrase indicates, Pármeno prefigures the future action as well. This forecast can be viewed by the audience as ominous in the light of his accurate recapitulation of the events in the garden. Severin has posited that "the past is seen as a form of fate converging on the present and impelling an unhappy future" (23).

When Pármeno learns that his tryst with Areúsa has been arranged, he abandons his previous obstinacy and concedes to Celestina "Que ya tropecé en no te creer cerca deste negocio con él [Calisto]" (196). Nonetheless, Pármeno's character has not yet undergone its complete transformation inasmuch as he reacts with a critical ear to Celestina's news that Melibea has agreed to a visit from Calisto. Pármeno restates this news from his personal perspective: "mucha sorpresa me pone el presto conceder de aquella señora, y venir tan aýna en todo su querer de Celestina (...)" (252).

Calisto, elated by his successful interview with Melibea and by the promise of future meetings, chides Pármeno, reminding him of his previous opposition to Celestina: ¿Qué te parece, Pármeno, de la vieja que tú me desalabavas?" (267). Pármeno explains away his objections by pointing out to Calisto: "Conoscia a Celestina y sus mañas" and "avisáuate como a Señor" (267). In his role as the responsible servant, Pármeno contends that he had no other choice. The recapitulations remind the audience that Pármeno has advised a cautious response to the news of Melibea's agreement with Calisto. That one who reasons so capably should later abandon reason, faced with Celestina's promise of sex with Areúsa first, and, second, with Sempronio's unrestrained greed, renders all the more tragic and ironic Pármeno's death. In this respect, Pármeno's character parallels Celestina's character: both of them abandon the familiar behavioral pattern the audience has come to associate with their charcaters.

The audience's attention is directed repeatedly to the contrast between Pármeno's expressed concern for Calisto's welfare and Sempronio's penchant for saying one thing and doing another. Lida de Malkiel states with regard to Sempronio: "Acertadas palabras, vida desacertada: tal parece la fórmula de este personaje" (LOA 594): Sempronio reproaches his master with the claim that Calisto is submitting "la dignidad del hombre a la perfeción de la flaca mujer" (94). He 
repeats his condemnation saying that women "conbidan, despiden, llaman, niegan, señalan amor, pronuncian enemiga, ensáñanse presto, apazíguanse luego, quieren que adevinen lo que quieren" (98). However, when Sempronio goes to Celestina's house and is confronted by Elicia, he declares to the girl: "Do yo vo, conmigo vas, and conmigo estás; no te aflijas, ni me atormentes más de lo que yo he padecido" (105). The irony expressed by the discrepancy between what Sempronio says on one occasion and then another has been noted also by Ayllón who writes that "Sempronio le aconseja a Calisto que no debe confiar en ninguna mujer y él confía en Elicia."11

Pármeno recalls for his master the conflicting advice offered by him and by Sempronio. He warns Calisto that "conozcerás mis agras palabras ser mejores para matar este fuerte cánçre que las blandas de Sempronio, que lo cevan, atizan su fuego, (...) añaden astillas que tenga que gastar hasta ponerte en tu sepoltura" (136). Like Pármeno's summary of the initial encounter in the garden, this is a further recapitulation by Pármeno, one the audience finds plausible and that includes another ominous prefiguring of Calisto's death. Sempronio has been presented as an unreliable character who says on thing and does another, ${ }^{12}$ and Pármeno's remark can be viewed by the audience as being more trustworthy. While the recapitulations contribute to the audience's increasing perception of the differences between Pármeno and Sempronio, they also underline the similarities to be found in the characterization of Sempronio and of Celestina.

Calisto's character can be defined most clearly in terms of his preoccupation with-initially, at least--his unrequited passion. Lida de Malkiel states that "la nota básica del carácter de Calisto es su egoísmo" (LOA 347). This portrayal is reinforced in the recapitulations. After the enamored Calisto has sworn: "Melibeo só y a Melibea adoro, y en Melibea creo y a Melibea amo" (93), he will himself restate this credo: "Por dios la creo, por dios la confesso, y no creo que hay otro soberano en el cielo" (95). While Calisto observes the rituals of religion, he is so blinded by his selfcentered passion that he succumbs to this form of blasphemy. ${ }^{13}$

"Cándido Ayllón, La perspectioa irónica de Fermando de Rojas (Madrid: Porrúa, 1984), 35. In this act-by-act study of irony, Ayllón shows how familiarity with the ironic perspective of the author of Celestina contributes to a fuller understanding of the realization of the characters.

${ }^{12}$ Sempronio advises Calisto: "Haz tú lo que bien digo y no lo que mal hago" (94).

13 "Lo característico de la pasión que se apodera de Calisto es que Melibea ocupa inmediatamente en su ánimo el lugar destinado al sentimiento religioso" (Ramiro de Maeztu, Don Quijote, Don Juan y La Celestina, $4^{2}$ ed.[Buenos Aires: Espasa-Calpe, 1943], 113). 
Sempronio reiterates Calisto's passionate state later when he explains that "Calisto arde en amores de Melibea"(107); these flames are those of the fires of lust. Calisto confirms this again to Sempronio: "No quiero consejo, ni esperarte más razones, que más abivas y enciendes las llamas que me consumen" (220). So wrapped up in these flames of passion is Calisto that he declares that death "alivio seria en tal caso deste mi tormento" (178). The memory of the initial encounter is brought back and seems intensified with each new recapitulation.

When the audience hears the following restatement: "Melibea es mi señora, Melibea es mi dios, Melibea es mi vida: yo su cativo, yo su siervo" (250), it can no longer entertain the notion of Calisto as courtly lover. He exceeds the bounds of the courtly tradition by not keeping her identity secret. Even Tristán, his paje, recounts the garden tryst, summing up in these words: "le alegra [a Calistol el muy gran plazer de lo que con su Melibea ha alcançado" (293). The audience can also note that Rojas injected additional irony into the tragic death of Calisto by having it take place at a point when he does seem to be unselfish in going to the aid of his servants.

The portrayal of Calisto as self-centered and lust-driven remains constant. However, Melibea's character evolves until her true nature is revealed. Recapitulations document and accentuate this progression. During Celestina's initial visit, Melibea recalls angrily that Calisto "començó a desvariar conmigo en razones, haziendo mucho del galán," but rationalizes affirming that "pensó que ya era todo suyo" (163). Celestina's fictitious tale of Calisto's toothache assuages Melibea somewhat and she shows remorse for her tirade: "!O quánto me pesa con la falta de mi paciencia!, porque siendo él ignorante y tú innocente, havés padescido las alteraciones de mi ayrada lengua" (168).

The outcome of the tale indeed reveals that "el egoísmo de Melibea es comparable al de Calisto, como el suyo, inseparable de la búsqueda del placer."14 But at this point (Act IV) Rojas directs the audience's attention to the attempted resolution of Celestina's quest as Calisto's emissary. Lucrecia, overhearing Melibea's request that Celestina return later; observes: "Secretamente quiere que venga Celestina" (168). Lida de Malkiel has pointed out that "notable es en Melibea su capacidad de acción" (LOA 411), and we here see Melibea assume an active role. In taking this step, she moves closer toward aligning her character with that of others who deal in deception and intrigue.

14 María Eugenia Lacarra, "La parodia de la ficción sentimental en la Celestina," Celestinesca 13, i (Mayo 1989): 24, nota 34. 
When Celestina recreates for Calisto this first visit to Melibea, she asserts that "queda abierta puerta para mi tornada" (177) since "el fin de su razón ly habla] fue muy bueno" (179). Celestina elects to highlight Melibea's change of attitude in her recapitulations. Melibea herself will return to this first visit of Celestina later (Act $X$ ), for its unsatisfactory resolution seems to plague her in a way similar to the way the rejection Calisto received in the huerta continues to plague him. She reflects: "¿Y no me fuera mejor conceder su petición y demanda ayer a Celestina quando de parte de aquel señor cuya vista me cativó me fue rogado, y contentarle a él, y sanar a mí (...)" (238). Here Melibea's genuine feelings are reflected. Up to this point Melibea's character remains aloof, as distinct from that of other characters who are collaborating with each other. But she rationalizes (to Lucrecia) that her will has been subverted: "ya as visto cómo no ha sido más en mi mano; cativóme el amor de aquel cavallero" (247). ${ }^{15}$

The key word in this recapitulation is "cativó," in which we sense a Melibea ensnared in the tangled web of courtly love. Celestina's account of her second visit to Melibea reinforces this philocaptio when she rejoices: "Que es más tuya que de sí mesma; más está a tu mandato y querer que de su padre Pleberio" (250). In the early stage of this affair Melibea's character was defined as falling within the context of the traditionally-reared daughter of a respected family. Now, on the other hand, the audience detects that the psychological battle for the will of Melibea is complete, that the forces of lust have won out and have defeated the last scruples of the stereotypical obedient daughter.

While it is true that the plausibility of Melibea's surrender to Calisto has been questioned on occasion, the recapitulations nevertheless confirm that the surrender, while seeming sudden, has in fact been gradual. Melibea, recall, protests to Lucrecia: "[M]i amor fue con justa causa. Requerida y rogada, cativa de su merecimiento, aquexada por tan astuta maestra como Celestina, servida de muy peligrosas vistaciones, antes que concediesse por entero en su amor" (305). In this pointed recapitulation, Melibea's memory of the chain of events permits speculation that perhaps her initial disdain owed more to Calisto's bold approach than to her feelings toward a proposed affair. If so, Celestina's intervention would appear less as a demonstration of her skills of persuasion than as a friendly presence which permits Melibea to act upon her second (secret) thoughts.

Fernando de Rojas' use of recapitulation techniques, in gradually allowing

15 "Esta lucha entre la voluntad y la naturaleza, en que la voluntad es vencida, es lo que da interés a su figura" (Maeztu, 115). 
Melibea's true nature to surface, intensifies the drama of the story. It becomes ironic that Melibea, following upon Calisto's death, in setting up her dramatic farewell scene, seems now to deliberate less carefully about the consequences of her actions than she had earlier, i.e., before accepting Calisto as her lover. The rashness of her suicide mirrors the brashness of Calisto in Act I, and it brings down the final curtain on the last of the remaining characters involved in the battle of wills at the center of the Tragicomedia.

The examples utilized in this study are representative of Rojas' use of the recapitulation techniques throughout. Sometimes a single recapitulation can serve multiple purposes. For example, the Act II passage discussed above, in which Pármeno rehearses the causes and effects leading to Calisto's current situation, serves the purpose of highlighting an aspect of the servant's character at the same time it both summarizes the earlier incident and prefigures Calisto's tragic fate.

The recapitulations used here to enhance Rojas' artistic skills lead to a psychological verisimilitude in which the audience can take delight. But they do more: through them, the audience is better prepared to savor fully the ironic remarks characters will make and to take part in the dramatic process by being privy to all of them and making external judgments about them throughout the reading. Recapitulations used in the area of characterization are only a portion of the uses made of them in Celestina. Valuable structurally, recapitulations can amplify the meaning of a scene for the audience, alter the pace of the action and contribute to the unity of the work. It is reasonable to posit that Rojaj' purposeful, judicious and skillful use of these techniques of recapitulation, make them a salient feature of his total art. The final, poignant recapitulation is left to the grieving Pleberio as he turns to face his daughter's corpse: "¿Por qué me dexaste triste y solo in hac lacrimarum valle?"(343). ${ }^{16}$

${ }^{16}$ Louise Fothergill-Payne, Seneca and "Cèlestina" (Cambridge: Cambridge UP, 1988). In this fine study, Fothergill-Payne proposes that the mention of sorrow and tears at the beginning of Act I (Celestina 88, 90,91) directed Rojas to Seneca's "Epistula 99" for a fitting conclusion to the work. 